\title{
Recent developments in automatic solid-phase extraction with renewable surfaces exploiting flow-based approaches
}

Miró, Manuel; Hartwell, Supaporn Kradtap; Jakmunee, Jaroon; Grudpan, Kate; Hansen, Elo Harald

Published in:

TrAC - Trends in Analytical Chemistry

Link to article, DOI:

10.1016/j.trac.2008.07.003

Publication date:

2008

Document Version

Early version, also known as pre-print

Link back to DTU Orbit

Citation (APA):

Miró, M., Hartwell, S. K., Jakmunee, J., Grudpan, K., \& Hansen, E. H. (2008). Recent developments in automatic solid-phase extraction with renewable surfaces exploiting flow-based approaches. TrAC - Trends in Analytical Chemistry, 27(9), 749-761. https://doi.org/10.1016/j.trac.2008.07.003

\section{General rights}

Copyright and moral rights for the publications made accessible in the public portal are retained by the authors and/or other copyright owners and it is a condition of accessing publications that users recognise and abide by the legal requirements associated with these rights.

- Users may download and print one copy of any publication from the public portal for the purpose of private study or research.

- You may not further distribute the material or use it for any profit-making activity or commercial gain

- You may freely distribute the URL identifying the publication in the public portal 


\title{
Recent developments in automatic solid-phase extraction with renewable surfaces exploiting flow based approaches
}

\author{
Manuel Miró $^{\mathrm{a}^{*}}$, Supaporn Kradtap Hartwell ${ }^{\mathrm{b}}$, Jaroon Jakmunee ${ }^{\mathrm{b}}$, \\ Kate Grudpan ${ }^{\mathrm{b}}$, Elo Harald Hansen ${ }^{\mathrm{c}}$
}

\begin{abstract}
a) Department of Chemistry, Faculty of Sciences, University of the Balearic Islands, Carretera de Valldemossa, km. 7.5, E-07122-Palma de Mallorca, Illes Balears, Spain.

b) Department of Chemistry, Faculty of Science, Chiang Mai University, Chiang Mai 50200, Thailand

c) Department of Chemistry, Technical University of Denmark, Kemitorvet, Building 207, DK-2800 Kgs. Lyngby, Denmark
\end{abstract}

\begin{abstract}
:
Solid-phase extraction (SPE) has been consolidated as the most versatile sample processing method for removal of interfering species and/or analyte enrichment. Although significant advances have been conducted over the past two decades for automation of the entire analytical protocol involving SPE via flow injection approaches, on-line SPE assays performed in a permanent mode lack sufficient reliability as a consequence of the progressive tighter packing of the bead reactor, contamination of the solid surfaces and potential leakage of functional moieties.

This article overviews the current state-of-the-art of an appealing tool for overcoming the above shortcomings, the so-called bead injection (BI) analysis, based on automated renewal of the sorbent material per assay exploiting the various generations of flow injection analysis. It addresses novel instrumental developments for implementation of BI and a number of alternatives for on-line chemical derivatization reactions and pinpoints the most common instrumental detection techniques utilised. Relevant environmental and bioanalytical applications reported within the past few years are presented and discussed in detail.
\end{abstract}

Keywords: solid-phase extraction, bead-injection, flow analysis, preconcentration, environment, bioassays

\footnotetext{
* Corresponding author. E-mail:manuel.miro@uib.es
} 


\section{Introduction}

The complexity of the matrices ofsamples in the environmental, biological, industrial and biotechnological fields along with the often low concentration levels of target species that might be encountered pose severe dilemmas for their direct determination even when exploiting even modern analytical instrumentation. This is a result of the dependence of the analytical readouts upon concomitant matrix components, and the fact that the concentration of analytes is often below the dynamic linear range of the detection device. Hence, there is a need for the development of simple, robust and reliable sample pretreatment procedures prior to the quantification step aimed at removing interfering matrix constituents and at the same time improving analyte detectability by preconcentration. When performed in a manual fashion, these preliminary operations are labour-intensive and time consuming, difficult to control systematically, and a source of major bias and accidental errors (e.g., sample contamination) that might have a decisive impact on the accuracy and precision of the analytical results.

The advent of the various generations of flow injection, that is, flow injection (FI), sequential injection (SI), Lab-on-Valve (LOV) and hybrid techniques for on-line/in-line sample processing has opened new perspectives as regards to automation and miniaturization of sample handling with the extra advantage of saving sample and reagent consumption and reducing waste generation $[1,2]$.

This review illustrates the current state-of-the-art of the so-called bead-injection (BI) technique which effects the entire solid-phase extraction (SPE) procedure in a renewable fashion in flowing systems. As opposed to earlier reviews dealing with BI [3-6], this article critically discusses the overall platforms described in the literature for BI-based SPE analysis and illustrates the alternative approaches for uptake and detection of target species . Pros and cons of BI assays as compared with conventional particle packed microcolumns for flowbased SPE are also described in detail via selection of representative examples in the environmental and bioanalytical fields as reported within the past decade.

\section{On-line SPE}

Sorptive extraction is the predominant sample processing method to be automated by resorting to flow systems as a consequence of its straightforward operation, high separation and preconcentration capabilities and minimum consumption of organic solvents. Most often it is employed by using packed-bed or disk-phase based microcolumns, which are filled with appropriate sorptive materials and placed within the flow network prior to the detection device. The ultimate goal is to improve the sensitivity of the analytical procedure and/or overcome the inherent low tolerance of the detection system to sample constituents by preconcentrating the analyte or removing interfering components from harsh milieus (e.g., high salt or protein content matrices) with no need for sample dilution. Several solid-phase reactors with different designs, mainly uniformly-bored or conical microcolumns, have been 
successfully assembled in flow-based set-ups. The temporary retention of low level concentrations of individual metal ions, nutrients and charged (bio)molecules by electrostatic interactions onto ion-exchange microcolumns or chelating reactors has been a common practice in flow-through SPE methods [7]. Derivatised non-polar metal chelates (e.g., iminodiacetates, dithiocarbamates, dithiophosphates or quinolinates) or hydrophobic species, such as organic pollutants, dyes and drugs, have been preconcentrated on reversed-phase materials (e.g., octadecyl-chemically modified silicagel, polytetrafluoroethylene (PTFE) beads or turnings, or multimodal polymeric sorbents) by partitioning, hydrophobic, or $\pi-\pi$ interactions $[1,7]$. The target compounds are either directly retained on the reactive surfaces after appropriate sorbent conditioning or in-line derivatized into a suitable chemical form. This extraction mode circumvents interfering effects from alkaline and alkaline earth elements when determining hazardous trace metals via intelligent selection of the chelating reagent [1].

As detailed above, flow-through SPE-procedures have been implemented by the use of permanent packed column reactors. These sorptive columns are however prone to problems in long term operation due to the progressively tighter packing or clogging of the column material resulting in increase of back pressure, which might be alleviated to some extent by back-flushing elution protocols. Further drawbacks of on-line SPE with reusable surfaces are the analyte carry-over effects, shrinking or swelling of the sorbent bed, malfunctions of the active entities including loss of functional moieties, the latter being a common problem for reagent impregnated bead materials, and, finally, surface deactivation due to irreversible sorption of interfering species. All these problems can be eliminated by adapting the concept of renewable surfaces, or as it has been termed bead injection (BI), that is, where the solidphase material, if called for, can be renewed for each analytical cycle.

\section{The concept of bead injection}

The BI approach originally adapted to optical sensing in sequential injection (SI) analyzers was introduced as a powerful tool for the automation of immunoassays using diffuse reflectometric detection [4]. The miniaturised BI chemosensors use minute amounts of beads carrying the derivatization reagent or functional moieties, whereby the analyte becomes preconcentrated and can be monitored via optical fibers in custom-built flow-through cells that capture the active sensing surfaces while allowing the perfused liquid to flow freely [4]. After each analytical run, the sorbent particles are disposed by flow-reversal and the sensor surface is renewed by injecting a new plug of a fresh bead suspension. This concept of optical sensing at solid surfaces, also termed solid-phase optosensing or BI spectroscopy, constitutes an attractive alternative to on-line SPE procedures with eluate detection for preventing the partial loss of the preconcentration capabilities gained during the sorption step as a result of the dilution of the eluate plug when delivered to the detector [8]. Moreover, BI fosters realtime monitoring of sorption process and thus detection relying on initial rate measurements can be readily accomplished. A further advantage of BI derived from its renewable fashion is 
the inherent flexibility for accommodation of reagent-based SPE assays with no stringent demands as to the full reversibility of the sorption/elution procedure. This is the case of uptake of Fe(II)-1,10-phenanthroline complex onto chelating beads because eluents such as nitric acid or EDTA are inefficient for quantitative stripping out of chelate from beads [9].

Notwithstanding the fact that both the optical paths and reaction times in BI-based schemes are shorter as compared with steady-state liquid-phase spectrophotometry, no deterioration in sensitivity is observed as a result of the immobilization of the analyte on a small surface area of the sensor wherein the reaction is driven by an excess of solid reagent [4].

In order to handle the bead material reproducibly within the automatic system, it is imperative to ensure the bead size homogeneity and the spherical shape of the reagentsupporting entities aiming at preventing the compact settlement into the conduits of the flow set-up. Hence, reversed-phase chemically modified silica gel lumps are not really suited for this purpose as a result of their irregular shape and size distribution [5]. On the other hand, bead material with a backbone of poly(styrene-divinylbenzene), poly(vinylpirrolidone) or agarose (e.g., Sephadex or Sepharose-type beads) fulfils the foregoing demands inasmuch as they are perfectly globe-shaped and of regular uniform size. The use of either micellar media or ancillary continuous recirculation schemes for the bead suspension [10] might be actually needed for reliable manipulation of hydrophobic sensing entities with higher density than water within the flow manifold.

\section{Instrumentation Development}

\subsection{Jet ring cell and rotating rod flow cell}

The instrumentation development for BI, initiated by Ruzicka and co-workers [4], is based on a SI network furnished with the so-called jet-ring cell. The name "jet ring" cell comes from the configuration and operation of the bead retention cell made as part of the flow conduit by inserting a solid rod to block the beads in the assigned space. As shown in Figure 1, the channel of the cell has an inner diameter slightly larger than the outer diameter of the blocking rod, forming the $O$-ring gap between the rod and the wall of the channel all around the rod. Only solutions are able to flow out while beads whose sizes are larger than the gap are packed due to the continuous incoming flow pushing the beads against the blocking rod. Used beads are discarded by the jet of solution reversely and rapidly flowing upstream.

For capture and release of beads as small as 5-7 $\mu \mathrm{m}$ in SI manifolds, a novel bead trapping strategy, the so-called rotating rod flow cell [11], was designed. The renewable sorbent microcolumn is created by first trapping larger beads $(>15 \mu \mathrm{m})$ in the flow cell, and then smaller beads bearing functional moieties are captured either within or on top of larger beads thus acting as a filter layer [12].

\subsection{Lab-on-valve}


The LOV approach hyphenated to SI set-ups should be viewed as a judicious advance towards the automation and miniaturization of bead injection schemes but within integrated microbore units [13]. The microconduit unit, made initially of Perspex, but more recently of hard polyvinylchloride, polyetheretherketone (PEEK) or polyetherimide (ULTEM), is a single monolithic structure mounted atop of the multiposition valve of an SI assembly, as illustrated in Fig. 2. Designed to incorporate all necessary laboratory facilities for a variety of analytical chemical assays, including in-valve manipulation of sorbent materials, hence the name lab-onvalve, it is made to contain microchannels working as the bead retention cell along with mixing points for chemical derivatization of the analyte if needed and a multipurpose flowthrough cell for real-time interrogation of analyte containing beads [13,14].

In short, packed column reactors are in-situ generated by aspirating beads from a peripheral port of the valve, advantage being taken of the fact that the sorbent in the LOV unit can be manipulated exactly as when handling liquids. The solid entities can even be automatically transported between different column positions within the micromachined unit, their retention within the columns being facilitated by fitting the column positions with appropriate stoppers (see Fig. 2), namely, up-down movable rods or the optical fibers themselves, which will keep hold of the beads, yet allow solutions to flow freely. In-valve detection could be realized at the eluate alike conventional SPE or by solid-phase optosensing [15].

As opposed to Lab-on-Chip (LOC) microdevices, the open architecture of the SI-LOV approach facilitates the implementation of BI protocols at will with no need for redesign of the unit. Readers are referred to a recent comprehensive review by Miró and Hansen [16] for a critical discussion of pros and cons of LOV as compared to LOC Microsystems for automated SPE.

\subsection{FI-BI with home made and commercial flow cells}

BI has also been adapted to FI systems as a cost-effective alternative of more sophisticated SI set-ups. The home made bead retention cell introduced by Grudpan's group $[9,17]$ was modified from the jet ring cell to suit the uni-directional flow normally employed in FI systems. The dedicated cell was furnished with an LED-based light source and a phototransistor detector at the opposite ends of the cell windows. Likewise the jet ring cell and LOV unit, the blocking rod leaves a minute space between the rod and the exit channel to let solution flow through while beads are retained. A mechanical movable blocking rod is used to control bead trapping and discarding instead of flow reversal. A solenoid actuator connected to the rod controls its movement. After each analysis, the rod is pulled back far enough to open the outlet and let the used beads flow out.

Commercially available flow-through cells commonly used in FI liquid-phase spectrophotometric detection have been adapted to BI spectroscopy by Molina-Díaz and coworkers [18-20]. Glass wool is used to plug the outlet of the flow cell to keep beads inside. Bead discarding is done by backward flushing the beads out with a high flow rate solution 
using an ancillary uni-directional peristaltic pump. Two Hellma-type flow cells, namely, 138 OS (1 mm light path, $50 \mu \mathrm{L}$ inner volume) and $176 \mathrm{QS}(1.5 \mathrm{~mm}$ light path, $25 \mu \mathrm{L}$ inner volume), were used for spectrophotometric [18,20] and fluorometric [19] optosensing, respectively. The configurations of both flow cells can be found in Hellma's cell catalog and works published by Molina Diaz's group [18-20]. In the current Hellma catalog, however, the flow cell model 138-OS is not available anymore. A drawback of the commercial flow cells is that the detection window is smaller than the bead volume, and therefore, not all product sorbed is monitored.

\subsection{Magnetic flow through cell}

Ruzicka and coworkers [21] proposed in the 90's a tubular BI cell design for magnetic bead based SI-immunoassays with detection of unbound labeled antibodies in the liquid phase, which was later extended to solid-phase optosensing by Imato's group [22,23] using a dedicated configuration for BI with luminescence detection. The magnetic beads involving functionalized agarose coated iron hydroxide particles are suitable for assays (e.g., immunoassays) involving several operational steps. A neodymium magnet or magnetic wire located under the (immuno)reactor is moved up and down by a solenoid magnet to trap the magnetic beads in place or let them flow with carrier solution. The configurations of the magnetic flow cell and SI network for BI-based chemiluminescence bioassays are illustrated in Fig 3. In this open tubular cell design, the continuously flowing stream of solution will less likely cause bead packing or clumping during multi-steps of washing and incubation as required in immunoassays. The most important limitation of this flow configuration for BI stems from the metallic nature of the bead core which impedes the monitoring of chemical reactions' development at low $\mathrm{pH}$ values.

\section{Analytical procedures for bead injection}

\subsection{Bead modification}

Although commercially available ion-exchangers or (co)polymeric beads can be directly utilized for BI, raw sorbents might be modified in the batch mode to incorporate appropriate moieties by physical or chemical binding with the bead surface or matrix for selective sorption or reaction with the analyte. As a consequence of the bead renewable nature, BI is well suited to overcome the most severe drawback of SPE procedures involving physical immobilization of reactants, i.e., the short lifetime of the loaded sorbent because of the gradual flushing out of the reagent during sample percolation.

For bioassays, antibodies or antigens [15,21-25] have been immobilized on magnetic [21,22] or polysaccharide-based $[24,25]$ beads. The latter have also been proven suitable as substrate for cell cultivation [26,27].

For environmental assays of trace metals, custom-made beads have been loaded with ligands (e.g., carbazides or azo compounds) in an off-line fashion $[28,29,30]$ because the 
time frame for quantitative impregnation of the bead surface then can be selected at will regardless of ligand sorption kinetics. As compared with on-line protocols, higher reagent concentration on the sorbent material is then ensured, which in turn should lead to improved enrichment factors and analyte breakthrough volumes. Optimization of immobilization protocols ( $\mathrm{pH}$ and reaction time) by measuring the rate and yield of reactions could be however performed at-line in SI-LOV by attaching a stirred bead microreactor to a peripheral port of the selection valve and real time monitoring of ligand uptake on bead surfaces [31].

\subsection{Analyte uptake}

Sorption of the analyte itself onto renewable ion-exchange resins has been a common practice for SI-LOV-BI determination of trace metal ions [5], although it could be equally exploited for uptake of charged drugs or biomolecules followed by UV-Vis or fluorometric measurements [32,33].

Analytes could be in principle retained also on the sorbent prior to addition of a chromogenic agent for heterogeneous on-bead derivatization prior to solid-phase spectrophotometric detection. For example, copper [34], iron [9] and mercury [35] were separated from sample matrices via sorption onto chelating resins prior to derivatization with ammonium pyrrolidine dithiocarbamate, 1,10-phenanthroline and dithizone, respectively. However, the approach is limited to those applications where the color development reaction proceeds rapidly with no elution of the chelate formed.

To tackle the above drawback, researchers have exploited homogeneous phase derivatization, that is, the analyte reacts in-line with the ligand before sorption of the resulted products on beads. This reaction might lead to improved retention selectivity and increased affinity of the analyte to the sorptive material. For example, trace metals after derivatization into a non-charged chelate or (co)precipitate are selectively sorbed on reversed-phase (e.g., PTFE or octadecyl-chemically modified copolymer) packing materials [18,36,37]. Indirect determination of drugs, e.g., promethazine and trifluoperazine, could be effected by on-line oxidation with $\mathrm{Fe}(\mathrm{III})$ with the subsequent complexation of the resulting $\mathrm{Fe}(\mathrm{II})$ with ferrozine followed by solid-phase spectrophotometric detection of the chelate onto anion-exchangers [18].

\subsection{Detection techniques}

A notable asset of BI is the inherent capability for hyphenation to many instrumental devices. Though most frequently used in combination with spectrophotometry [9,15,17,20,24,25,35], BI spectroscopy has been also found applications involving fluorometric [12,19] and chemiluminescence [22,23] detection. The most important requirement for BI spectrophotometry is the optical transparency of beads to prevent high signal background and light scattering effects. It should be noted that not merely single but biparametric BI-based spectrophotometric or spectrofluorometric sensors have been designed for determination of 
trace elements (e.g., $\mathrm{Zn}$ and $\mathrm{Cu}$ or $\mathrm{Al}$ and $\mathrm{Be}$ ) using a non-selective chelating reagent and selective elution or sorption protocols $[19,20]$. Unfortunately, sequential assays were required because of limited chromatographic resolution of the BI columns.

Coupling of BI with ETAAS with direct introduction of metal loaded sorbent into the graphite furnace is feasible for polymeric organic beads (e.g., Sephadex or Sepharose) because of pyrolysis of the beads prior to metal atomization [5]. Besides the aforementioned detectors, BI has been coupled to voltammetric [26], ICP-MS [5], AFS [38Fejl! Bogmærke er ikke defineret.,37], mass spectrometric [39] and radiometric [40] measurements, although eluate detection was in all instances called for.

\section{Applications of flow-through BI}

In this section, relevant applications of BI in both the environmental and the bioanalytical fields are overviewed. Table 1 compiles the analytical performance of such methods, including the sorbent material, the flow approach, the detection technique, the dynamic linear range, the detection limit, the precision and the sample matrix.

\subsection{Environmental assays}

Most of the work conducted in this field has been focused on determination of trace level concentrations of inorganic elements in harsh environmental matrices containing high levels of dissolved salts, such as seawater, brines or soils [29,36,41]. To this end, matrix separation with concomitant metal/metalloid enrichment has been effected using SI-LOV-BI preconcentration and eluate detection by ETAAS or AFS. SI-BI is also a suitable platform for accommodation of trace metal speciation assays, e.g., $\mathrm{Cr}(\mathrm{III})$ and $\mathrm{Cr}(\mathrm{VI})$, via selective retention of oxidation states in appropriate sorbent materials, e.g, cation and anionexchangers, or via sequential determinations of a single species and total inorganic metal following in-line homogeneous/heterogeneous redox reactions and preconcentration in a given sorptive microcolumn [42]. Readers are referred to the comprehensive review article in [43] for further details as to the designs and analytical performance of SI-BI-LOV methods for trace metal determinations in environmental matrices.

Recent trends are devoted to the exploitation of hybrid flow systems, e.g., multisyringe flow injection (MSFI) analysis, in combination with BI-LOV to expand the scope of these miniaturized systems $[38,44]$. It should be borne in mind that SI-BI-LOV manifolds are not well suited for implementation of post-LOV derivatization reactions because of the need in SI-LOV of having to aspirate the overall solutions in a holding coil. On the other hand, the interfacing of BI-LOV with MSFI enabled the sorptive preconcentration and determination of hydride generating species by on-line derivatization of eluate with sodium tetrahydroborate prior to AFS detection [38]. Despite the divergent kinetics of analyte sorption and hydride generation, optimal experimental conditions for both reactions were affixed in a sole flow 
network owing to discontinuous flow nature of the MSFI technique and the flexibility of the approach for providing variable flow rates at will [38].

$\mathrm{BI}$ in an LOV fashion has not been merely applied to sorptive preconcentration of metal species but organic pollutants as well prior to reversed-phase liquid chromatographic (LC) separations as demonstrated by determination of anti-inflammatory drugs in raw wastewaters using multimodal copolymeric beads with no need for ancillary sample treatment [. The marriage of BI-LOV with MSFI was proven suitable for quantitative elution of sorbed drugs whilst efficient LC band focusing of eluate was also ensured.

\subsection{Cellular assays/activities}

Cellular assays are crucial for studies of new pharmaceutical candidates and their reaction protocols. These studies normally involve loading of various doses of a given drug on cells, monitoring the reaction and detection of cell responses in a batchwise mode. These processes require techniques that can handle living cells reliably by preventing deterioration of cells, while assuring reproducible timing and precise injection of minute volumes of reagents. BI has actually played an outstanding role in the improvement of cellular assays. [45] Hodder and Ruzicka [46] introduced in 1999 a novel application of SI-BI by using beads as micro-carriers of living cells to measure elevation of intracellular calcium. High density of cells could be trapped in the small inner volume of a jet ring cell which was placed above a fluorescence microscope objective lens. The beauty of this approach is that a fresh portion of cells is exposed to a given concentration of chemical and replaced for each assay. The investigation of cell response to a given drug or chemical is thus done more accurately than classical approaches because of the absence of carryover effects and loss of cell activity over time. The continuous monitoring of signal changes at the beads provided peak profiles that yielded valuable information on the kinetics of cellular assays and concentration threshold of reagent, agonist in this case, that causes cell response.

Similar uses of beads as micro-carriers for living cells were extended to LOV [26]. For example, consumption of glucose and extrusion of lactate could be detected sensitively and rapidly due to the high concentration of immobilized cells [47]. The exploration of cellular activities based on the release of proton from cells in LOV was also reported [27]. Though bead injections were done manually here, two micro-packed bead columns were uniquely created within one section of the LOV micro-channel, as shown in Figure 4A. Beads carrying cells were retained upstream to the beads with immobilized $\mathrm{pH}$ indicator. Protons extruded from cells were accumulated during the stopped flow and were pushed to react with the immobilized indicator, causing the color change on the indicator beads which could be invalve monitored by solid phase spectrophotometry (see Fig. 4D). The flow set-up illustrated in Fig 4B was proposed as an alternative to more complicated molecular devices and to replace the no longer commercially available light addressable potentiometric sensor for 
measurement of extracellular acidification rates which frequently has been utilized for evaluation of metabolic functions.

\subsection{Kinetic affinity studies and affinity chromatography}

Ogata et al [39] illustrated in 2002 that BI-LOV could be used effectively as an automatic system for investigation of kinetic affinity capture and release of biomolecules. Model studies were conducted with a well known noncovalent binding between streptavidin coated beads and biotinylated conjugates. Further work of the authors' group was devoted to the development of the beta-galactosidase assay in human skin fibroblasts using on-line ionexchange and electrospray ionization mass spectrometry [39]. This work reveals the flexibility of LOV as a front end to many analytical instrumentas besides optical-fiber spectrophometers.

A similar miniaturized set up was exploited by Ruzicka and co-workers for critical comparison of BI spectroscopy with affinity chromatography (or more precisely "affinity extraction"), which involves eluate detection, on the course of bioassays [15]. Preliminary studies evidenced that results obtained from the two different modes of detection complemented each other and gave a complete picture of biomolecular association and dissociation between target biomolecules and bioligands immobilized onto bead surfaces. However, while affinity chromatography offers improved sensitivity as compared to BI spectroscopy (detection limits are $>10$-fold better), the latter offers unique possibilities for monitoring biomolecules irreversibly bound to the chromatographic column.

\subsection{Immunoassays}

The precise micro-fluidic manipulation and timing inherent to SI-LOV combined with the concept of renewable solid surfaces make possible to perform multiple step protocols, e.g., immunoassays, automatically [24,25]. In-valve bead retention was accomplished by use of jet/nozzle plug and fiber optics as previously designed for other LOV applications. Both label dilution immunoassay for determination of goat, anti-mouse IgG [24] and ELISA for detection of GAD65 antibodies [25] were demonstrated. Although low sample throughput is a limitation as compared to standard 96-well plate immunoassay, much shorter time per assay cycle (less than $30 \mathrm{~min}$ vs. $5-8 \mathrm{~h}$ ) is suitable for immediate clinical feedback and low to medium numbers of samples. In addition, the micro-fluidic computer-controlled analyzer requires much lower sample volume (50 $\mu \mathrm{L}$ or less vs. $200-400 \mu \mathrm{L})$ and precludes the need of experienced medical technicians.

\subsection{Purification and quantitation of DNA and specific biomarkers}

BI-LOV has been recently proposed as a platform for determination of nucleic acids. The use of silica gel as a renewable SPE material for purification of DNA from whole human blood was demonstrated [48]. Beads were packed within an LOV cavity to retain DNA which was 
later eluted for PCR amplification and electrophoretic separation. DNA purification was monitored on-line by post-column fluorimetry using ethidium bromide as a derivatization reagent. Other researchers used specially functionalized beads for elucidation and quantitative determination of specific DNA sequences $[49,50]$. The improved sensitivity gained by BI spectroscopic detection allowed determination of DNA at the pmol level [49]. This system might be ultimately applied to any assay involving identification of life-threatening microorganisms.

Hartwell et al [51] incorporated wheat germ bearing beads in an FI-BI assembly for determination of bone specific alkaline phosphatase. Detection can be done easier as compared to conventional wheat germ agglutination technique. In addition, the increase in surface area of micro-beads for immobilization of reagent with respect to the inner surface of the micro-well used in ELISA permits a better differentiation between osteoporosis patient group and normal group.

Readers are encouraged to peruse the following critical reviews [32,33] for a comprehensive overview of LOV applications within the bioanalytical field.

\section{Future trends}

It is to be expected that $\mathrm{BI}$ in the different formats will be further developed in the years to come for high throughput analysis/screening in various analytical fields. Coupling of LOV with affinity chromatography with various detection systems including BI spectroscopy, mass spectrometry, amperometry or fluorometry is expected to be well suited to currents demands in bioanalytical sciences including natural product researches, drug discovery, proteins and DNA analyses as well as in clinical-and medical analyses for rapid screening and diagnostics.

SI-LOV-BI offers significant potentials in the environmental field for removal of matrix ingredients in leachates and concomitant analyte enrichment following on-line leaching tests of environmental solids (e.g., soils or sediments) packed in microcolumns attached to the peripheral ports of multiposition valve [41]. It should be noted that there has not yet been any report on an attempt for investigation of sorptive capabilities of materials (e.g., soil layers for trace elements) by utilizing flow systems furnished with on-line solid column reactors. Leaching/sorption schemes might be extended to radioisotopes as tracers or essential ingredients of isotope dilution in geochemical studies or as analytes in nuclear technological studies involving nuclear waste storage and management. Applications of BI systems with radiochemical detection for automation in handling radioactive materials in a closed system would be also very useful practice for nuclear medicine and nuclear reactor management.

It would be also interesting to explore the combination of BI with field flow fractionation as a tool for gaining knowledge on size and distribution of low level concentration of macromolecules. This should be useful for environmental and clinical investigations. 
As regards to new sorptive materials, molecularly imprinted polymeric spheres, prepared by suspension polymerization, precipitation polymerization or multi-step swelling polymerization [52], which feature improved selectivity for a given target analyte or group analogous are expected to be exploited for BI spectroscopy or BI sorbents prior to LC separations.

\section{ACKNOWLEDGEMENTS}

Manuel Miró is indebted to the Conselleria d'Economia, Hisenda i Innovació del Govern de les Illes Balears (Spain) for supporting the project PROGECIB-1A. Supaporn Kradtap Hartwell, Jaroon Jakmunee and Kate Grudpan thank Commission on Higher Education of Thailand for Research Group (RG) grant. The Center for Innovation in Chemistry:

Postgraduate Education and Research Program in Chemistry (PERCH-CIC) and the Thailand Research Fund are also acknowledged for additional support. 


\section{Figure legends}

Figure 1. Diagram of a jet ring cell and operation of bead injection (packing and renewal steps). Reproduced from J. Ruzicka, Flow Injection Analysis CD-ROM Tutorial, 3rd Ed., 2004; Published by FIAlab Instruments, Inc., with the author's permission.

Figure 2. Schematic illustration of an SI-LOV set-up for BI optosensing. The inset shows a magnified close-up of the micromachined LOV unit. Reproduced from J. Ruzicka, Flow Injection Analysis CD-ROM Tutorial, 3rd Ed., 2004; Published by FIAlab Instruments, Inc., with the author's permission.

Figure 3 (a) SI manifold for chemiluminescence immunoassay of vitellogin using magnetic microbeads (b) Illustration of the dedicated flow-through cell for retention of antibody bearing magnetic beads. Vg: Vitellogin, HRP: Horseradish peroxidase. Reproduced from ref. 20 by permission of Elsevier Ltd.

Figure 4. Sketch of an SI-LOV manifold for measurement of proton extrusion from living cells using two different packed-bed columns. A), B), and D) Magnified views of bead columns (cell beads and $\mathrm{pH}$ indicator beads) implemented within LOV microconduits. B) Detailed diagram of SI components for BI spectroscopy of $\mathrm{pH}$ indicator beads. Reproduced from ref. 25 by permission of Royal Society of Chemistry. 
Figure 1

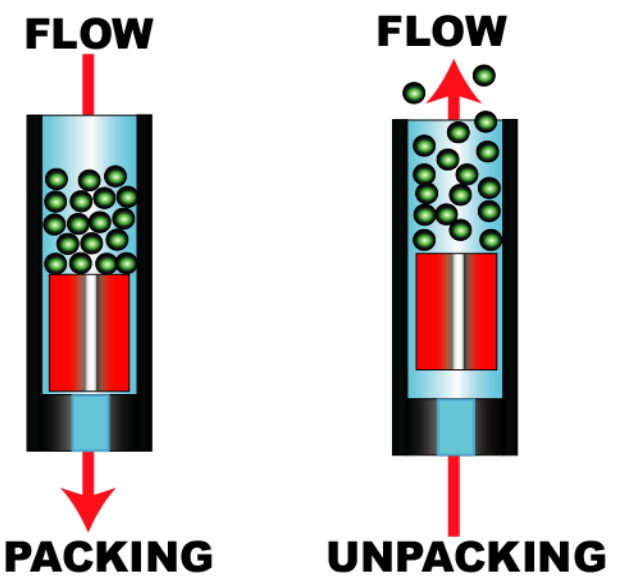

14 
Figure 2

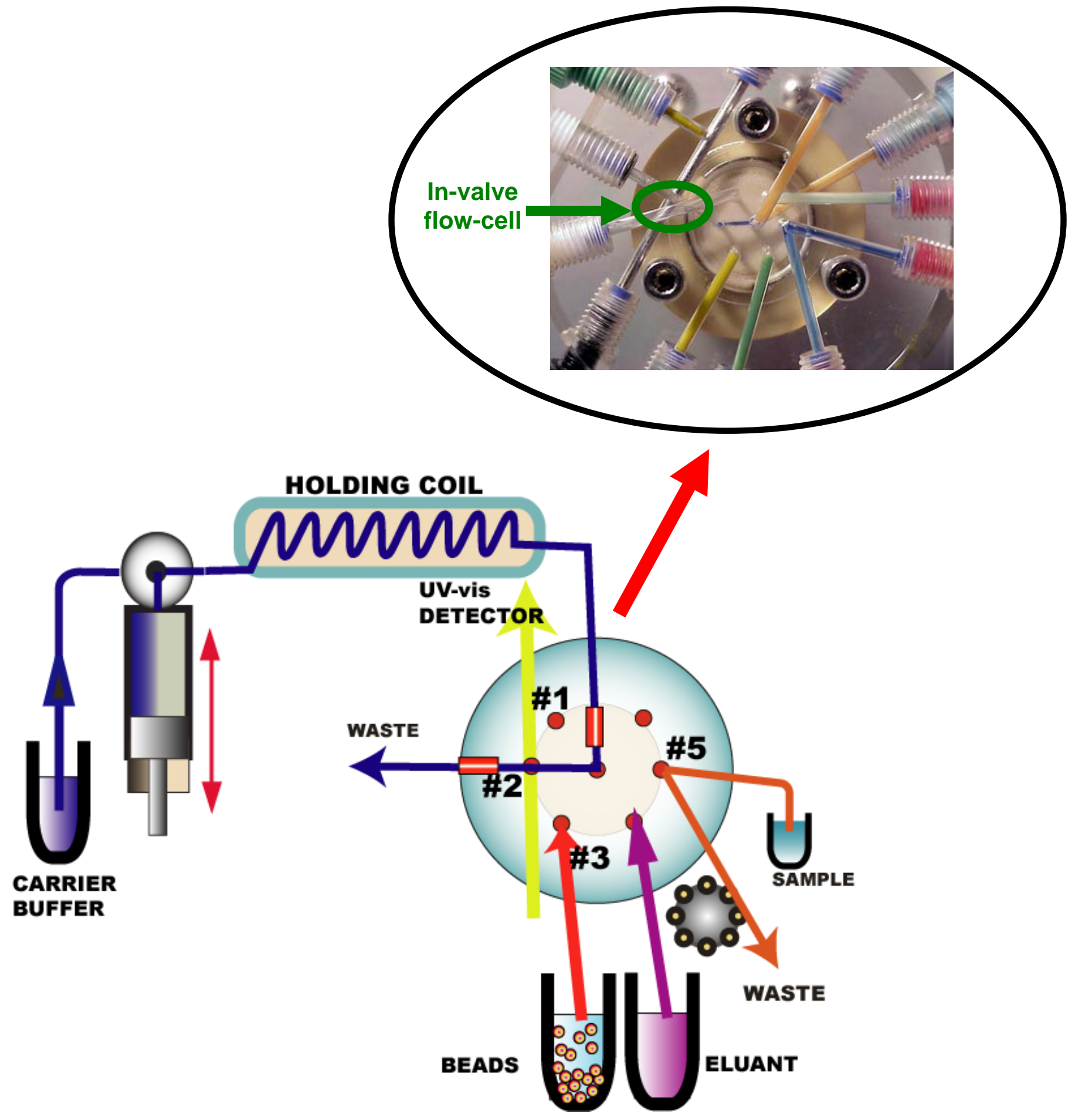




\section{Figure 3}
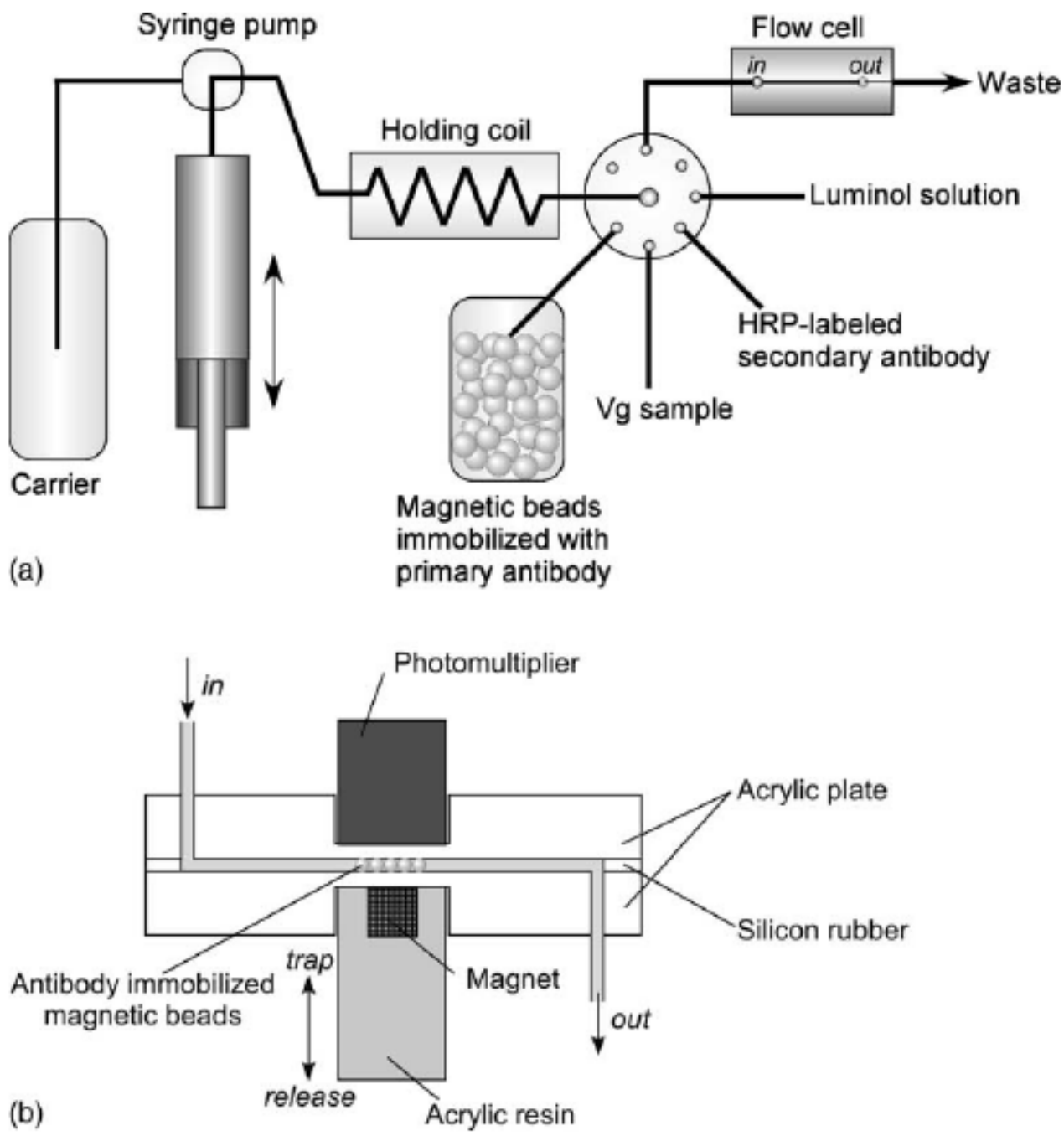
Figure 4

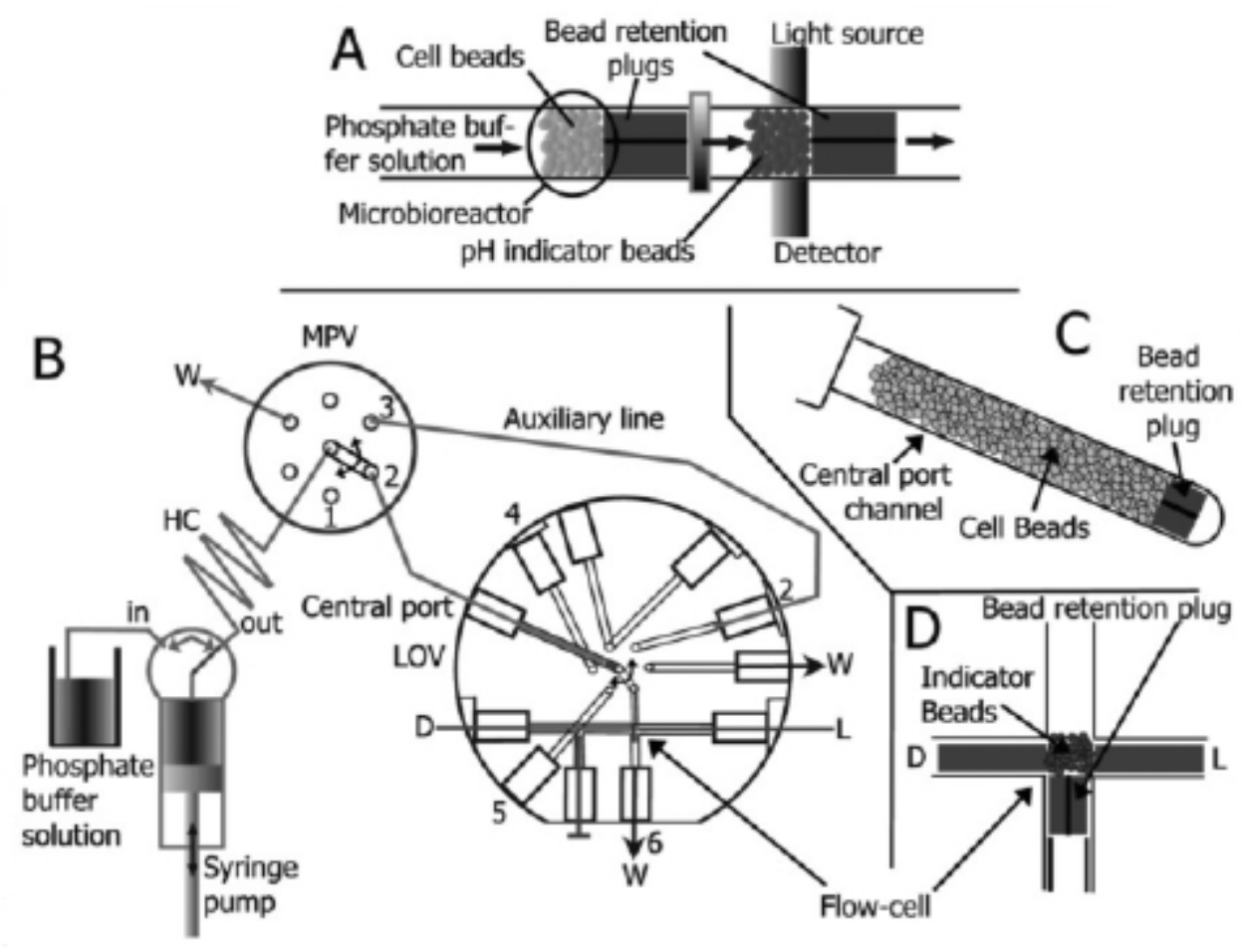




\section{REFERENCES}

[1] M. Miró, E.H. Hansen, On-line processing methods in flow analysis. In: Advances in Flow Methods of Analysis, M. Trojanowicz (Ed), Wiley-VCH, Weinhem, Chap. 11, in the press.

[2] E.H. Hansen, M. Miró, Trends Anal. Chem. 26 (2007) 18

[3] S. Kradtap-Hartwell, G.D. Christian, K. Grudpan, Trends Anal. Chem., 23 (2004) 619.

[4] J.Ruzicka, L. Scampavia, Anal. Chem., 71 (1999) 257A.

[5] J.-H. Wang, E.H. Hansen, M. Miró, Anal. Chim. Acta 499 (2003) 147.

[6] E.H. Hansen, M. Miró, Appl. Spectrosc. Rev., 43 (2008) 335.

[7] M. Miró, E.H. Hansen, Trends Anal. Chem. 25 (2006) 267.

[8] M. Miró, W. Frenzel, Trends Anal. Chem. 23 (2004) 11.

[9] P. Ampan, S. Lapanantnoppakhun, P. Sooksamiti, J. Jakmunee, S. Kradtap-Hartwell, S. Jayasvati, G.D. Christian, K. Grudpan, Talanta 58 (2002) 1327

[10] M. Miró, S. Jónczyk, J.-H. Wang, E.H. Hansen, J. Anal. At. Spectrom. 18 (2003) 89. [11]C. J. Bruckner-Lea, M. S. Stottlemyre, D. A. Holman, J. W. Grate, F. J. Brockman, D. P. Chandler, Anal. Chem. 72 (2000) 4135.

[12] J. W. Grate, C. J. Bruckner-Lea, A. E. Jarrell, D. P. Chandler Anal. Chim. Acta 478 (2003) 85 .

[13] J. Ruzicka, Analyst 125 (2000) 1053

[14] J.-W. Wang, E.H. Hansen, Trends Anal. Chem. 22 (2003) 225.

[15] Y. Gutzman, A. D. Carroll, J. Ruzicka, Analyst, 131 (2006) 809.

[16] M. Miró, E.H. Hansen, Anal. Chim. Acta 600 (2007) 46.

[17] K. Jitmanee, S. Kradtap-Hartwell, J. Jakmunee, S. Jayasvasti, J. Ruzicka, K. Grudpan, Talanta 57 (2002) 187.

[18] M.J. Ruedas-Rama, A. Ruiz-Medina, A. Molina-Díaz, J. Pharm. Biomed. Anal. 35 (2004) 1027.

[19] M.J. Ruedas-Rama, A. Ruiz-Medina, A. Molina-Díaz, Talanta 66 (2005) 1333.

[20] M.J. Ruedas-Rama, A. Ruiz-Medina, A. Molina-Díaz, Anal. Sci., 21 (2005) 1079

[21] C.H. Pollema, J. Ruzicka, G. D. Christian, Å. Lernmark, Anal. Chem., 64 (1992) 1356

[22] N. Soh, H. Nishiyama, Y. Asano, T. Imato, T. Masadome, Y. Kurokawa, Talanta 64 (2004) 1160.

[23] R.-Q. Zhang, H. Nakaima, N. Soh, K. Nakano, T. Masadome, K. Nagata, K. Sakamoto, T, Imato, Anal. Chim. Acta 600 (2007) 105.

[24] A. D. Carroll, L. Scampavia, J. Ruzicka, Analyst 127 (2002) 1228.

[25] A. D. Carroll, L. Scampavia, D. Luo, Å Lernmark, J. Ruzicka, Analyst 128 (2003) 1157.

[26] I. Lähdesmäki, Y.K. Park, A.D. Carroll, M. Decuir, J. Ruzicka, Analyst 132 (2007) 811.

[27] H. A. Erxleben, M. K. Manion, D. M. Hockenbery, L. Scampavia, J. Ruzicka, Analyst 129 (2004) 205 
[28] M. J. Ruedas-Rama, A. Ruiz-Medina, A. Molina-Díaz, Anal. Bioanal. Chem., 376 (2003) 527

[29] X.-B. Long, M. Miró, E.H. Hansen, Anal. Chem. 77 (2005) 6032

[30] P. Ampan, J. Ruzicka, R. Atallah, G. D. Christian, J. Jakmunee, K. Grudpan, Anal.

Chim. Acta 499 (2003) 167

[31] J. Ruzicka, A.D. Carroll, I. Lähdesmäki, Analyst 131 (2006) 799.

[32] X.-W. Chen., J.-H. Wang, Anal. Chim. Acta 602 (2007) 173

[33]M.D. Luque de Castro, J. Ruiz-Jiménez, J.A. Pérez-Serradilla Trends Anal. Chem. 27

(2008) 118.

[34] S. Kradtap-Hartwell, A. Boonmalai, S. Jayasvati, S. Lapanantnoppakhun, J. Jakmunee,

K. Grudpan, Anal. Sci., 21 (2005) 437

[35] E. C. Vidotti, V. C. Almeida, C. C. Oliveira, Talanta 64 (2004) 993

[36] X.-B. Long, M. Miró, R. Jensen, E.H. Hansen, Anal. Bioanal. Chem. 386 (2006) 739

[37] Y. Wang, M.-L. Chen, J.-H. Wang, J. Anal. At. Spectrom. 21 (2006) 535

[38] X.-B. Long, M. Miró, E. H. Hansen, J. M. Estela, V. Cerdà, Anal. Chem. 78 (2006) 8290

[39] Y. Ogata, L. Scampavia, J. Ruzicka, C.R. Scott, M. H. Gelb, F. Turecek, Anal. Chem. 74 (2002) 4702

[40] O. Egorov, M. J. O'Hara, J. W. Grate, J. Ruzicka, Anal. Chem. 71 (1999) 345.

[41] X.-B. Long, M. Miró, E.H. Hansen, Analyst 131 (2006) 132

[42] X.-B. Long, M. Miró, E.H. Hansen, J. Anal. At. Spectrom. 20 (2005) 1203.

[43] E.H. Hansen, M. Miró, X.-B. Long, R. Petersen, Anal. Lett. 39 (2006) 1243

[44] J.B. Quintana, M. Miró, J.M. Estela, V. Cerdà, Anal. Chem. 78 (2006) 2832

[45] A.M. Pimenta, M.C.B.S.M. Montenegro, A. N. Araujo, J. Martínez-Calatayud, J. Pharm. Biomed. Anal. 40 (2006) 16.

[46] P.S. Hodder, J. Ruzicka, Anal. Chem. 71 (1999) 1160.

[47] C.M. Schulz, L. Scampavia, J. Ruzicka, Analyst 127 (2002) 1583.

[48]X.-W. Chen, Z.-R. Xu, B.-Y. Qu, Y.-F. Wu, J. Zhou, H.-D. Zhang, J. Fang, J.-H. Wang, Anal. Bioanal. Chem., 388 (2007) 157.

[49] K.A. Edwards, A. J. Baeumner Anal. Chem. 78 (2006) 1958.

[50] M. Decuir, I. Lähdesmäki, A. D. Carroll, J. Ruzicka, Analyst 132 (2007) 818.

[51] S. Kradtap-Hartwell., D. Somprayoon, P. Kongtawelert, S. Ongchai, O. Arpornchayanon,

L. Ganranoo, S. Lapanantnoppakhun, K. Grudpan, Anal. Chim. Acta, 600 (2007) 188.

[52] N. Pérez-Moral, A.G. Mayes, Anal. Chim. Acta, 504 (2004) 15. 
Table 1-Analytical performance of representative flow-based sorbent extraction methods involving bead injection analysis

\begin{tabular}{|c|c|c|c|c|c|c|c|c|}
\hline Analyte & $\begin{array}{c}\text { Flow } \\
\text { system }\end{array}$ & Bead type & $\begin{array}{l}\text { Detection } \\
\text { technique }\end{array}$ & Detection limit & Linear range & Precision & Sample/ Application & Ref \\
\hline \multicolumn{9}{|c|}{ Metal and metalloid species } \\
\hline $\mathrm{Fe}$ & FI & $\begin{array}{l}\text { Iminodiacetate } \\
\text { chelating resin } \\
\text { (Chelex-100) } \\
\end{array}$ & Spectrophotometry & $0.2 \mu \mathrm{g} / \mathrm{L}$ & $0.5-6 \mu g$ & NR & Beer & 9 \\
\hline $\mathrm{Cd}$ & SI-LOV & $\begin{array}{c}\mathrm{C}_{18} \text {-PS/DVB and } \\
\text { PTFE }\end{array}$ & ETAAS & $\begin{array}{c}5 \mathrm{ng} / \mathrm{L}(\mathrm{PTFE}) \text { and } \\
135 \mathrm{ng} / \mathrm{L}\left(\mathrm{C}_{18}\right)\end{array}$ & $\begin{array}{l}0.05-1 \mu \mathrm{g} / \mathrm{L}(\mathrm{PTFE}) \\
\text { and } \\
0.2-1.5 \mu \mathrm{g} / \mathrm{L}\left(\mathrm{C}_{18}\right)\end{array}$ & $\begin{array}{c}4.3 \% \text { (PTFE) } \\
\text { and } 3.4 \% \\
\left(\mathrm{C}_{18}\right)\end{array}$ & $\begin{array}{c}\text { CRM } 279 \text { (Sea Lettuce), } \\
\text { CRM } 320 \text { (River } \\
\text { sediment), NIST } 1640 \\
\text { (Natural water) and } \\
\text { human urine } \\
\end{array}$ & 10 \\
\hline Fe & FI & Chelex-100 & Spectrophotometry & $25 \mu \mathrm{g} / \mathrm{L}$ & Up to $217 \mu \mathrm{g} / \mathrm{L}$ & $4 \%$ & $\begin{array}{c}\text { Spiked tap and drinking } \\
\text { water }\end{array}$ & 17 \\
\hline $\mathrm{V}(\mathrm{V})$ & FI & $\begin{array}{c}\text { Sephadex QAEA-25 } \\
\text { loaded with ARS } \\
\end{array}$ & Fluorometry & $0.45 \mu \mathrm{g} / \mathrm{L}$ & $2-60 \mu \mathrm{g} / \mathrm{L}$ & $4.22 \%$ & $\begin{array}{c}\text { Water, serum, urine and } \\
\text { mussel tissues }\end{array}$ & 19 \\
\hline $\mathrm{Cu}$ and $\mathrm{Zn}$ & FI & $\begin{array}{l}\text { Sephadex QAEA-25 } \\
\text { loaded with Zincon }\end{array}$ & Spectrophotometry & $\begin{array}{c}29 \mu \mathrm{g} / \mathrm{L} \mathrm{Cu} \text { and } \\
40 \mu \mathrm{g} / \mathrm{L} \mathrm{Zn}\end{array}$ & $\begin{array}{c}50-1000 \mu \mathrm{g} / \mathrm{L} \mathrm{Cu} \\
\text { and } \\
100-1800 \mu \mathrm{g} / \mathrm{L} \mathrm{Zn} \\
\end{array}$ & $<5 \%$ & $\begin{array}{l}\text { Water, pharmaceutical } \\
\text { preparation, soil and hair }\end{array}$ & 20 \\
\hline Co & FI & $\begin{array}{c}\text { Dower } 50 \mathrm{~W} \text { loaded } \\
\text { with PAN }\end{array}$ & Spectrophotometry & $19 \mu \mathrm{g} / \mathrm{L}$ & $50-2000 \mu \mathrm{g} / \mathrm{L}$ & $4.16 \%$ & $\begin{array}{c}\text { Water, pharmaceutical } \\
\text { formulation, steel }\end{array}$ & 28 \\
\hline $\mathrm{Cr}(\mathrm{VI})$ & SI-LOV & $\begin{array}{c}\mathrm{C}_{18}-\mathrm{PS} / \mathrm{DVB} \\
\text { impregnated with } \\
\text { DPC }\end{array}$ & ETAAS & $0.03 \mu \mathrm{g} / \mathrm{L}$ & $0.12-1.5 \mu \mathrm{g} / \mathrm{L}$ & $3.8 \%$ & $\begin{array}{c}\text { NIST } 1640 \text { (Natural } \\
\text { Water), tap water and } \\
\text { seawater }\end{array}$ & 29 \\
\hline $\mathrm{Pb}$ & SI-LOV & $\begin{array}{c}\text { Sephadex G-25 } \\
\text { impregnated with } \\
\text { dithizone } \\
\end{array}$ & ETAAS & $0.3 \mathrm{ng}$ & $1-4 \mathrm{ng}$ & $1.9 \%$ & Standard solutions & 30 \\
\hline $\mathrm{Cu}$ & FI & Chelex-100 & Spectrophotometry & $10 \mu \mathrm{g} / \mathrm{L}$ & $0.01-1.0 \mathrm{mg} / \mathrm{L}$ & NR & $\begin{array}{l}\text { swimming pool water } \\
\text { and supplement tablets }\end{array}$ & 34 \\
\hline $\mathrm{Cu}$ and $\mathrm{Hg}$ & SI & Chelex-100 & Spectrophotometry & $\begin{array}{c}0.63 \mu \mathrm{g} / \mathrm{L} \mathrm{Cu} \text { and } \\
0.25 \mu \mathrm{g} / \mathrm{L} \mathrm{Hg} \\
\end{array}$ & $\begin{array}{c}\text { 5-500 } \mu \mathrm{g} / \mathrm{L} \mathrm{Cu} \text { and } \\
2.5-30 \mu \mathrm{g} / \mathrm{L} \mathrm{Hg} \\
\end{array}$ & $\begin{array}{c}5.2 \% \mathrm{Cu} \text { and } \\
9.4 \% \mathrm{Hg} \\
\end{array}$ & River water & 35 \\
\hline $\mathrm{Ni}$ & SI-LOV & $\begin{array}{l}\text { poly-DVB-co-N- } \\
\text { vinylpyrrolidone }\end{array}$ & ETAAS & $0.05 \mu \mathrm{g} / \mathrm{L}$ & $0.2-2 \mu \mathrm{g} / \mathrm{L}$ & $<5.6 \%$ & $\begin{array}{c}\text { Hard tap water, seawater } \\
\text { and NIST } 1640\end{array}$ & 36 \\
\hline $\mathrm{Cd}$ & SI-LOV & C18-PS/DVB & Hg-AFS & $3.5 \mathrm{ng} / \mathrm{L}$ & NR & $1.6 \%$ & $\begin{array}{c}\text { CRM } 320 \text { (River } \\
\text { sediment), CRM } 279 \\
\text { (Sea Lettuce) and GBW } \\
09139 \text { (Cattle blood) } \\
\end{array}$ & 37 \\
\hline As & SI- & Q-sepharose & HG-AFS & $20 \mathrm{ng} / \mathrm{L}$ & $0.05-2.0 \mu \mathrm{g} / \mathrm{L}$ & $5.7 \%$ & Tap and underground & 38 \\
\hline
\end{tabular}




\begin{tabular}{|c|c|c|c|c|c|c|c|c|}
\hline & $\begin{array}{l}\text { LOV- } \\
\text { MSFI }\end{array}$ & (anion exchange) & & & & & $\begin{array}{c}\text { water and SRMs } \\
\text { (TMDA-54.3 Lake water } \\
\text { and ERM-CA010-Hard } \\
\text { drinking water) } \\
\end{array}$ & \\
\hline Cr (VI) & SI-LOV & $\begin{array}{c}\text { Q-sepharose } \\
\text { (anion exchange) }\end{array}$ & ETAAS & NR & $0.02-0.6 \mathrm{ng}$ & $<6.8 \%$ & $\begin{array}{c}\text { SRM } 2709 \text { San Joaquin } \\
\text { Soil/On-line leaching } \\
\text { investigations }\end{array}$ & 41 \\
\hline $\begin{array}{l}\mathrm{Cr}(\mathrm{III}) \text { and } \\
\mathrm{Cr}(\mathrm{VI})\end{array}$ & SI-LOV & Chelating Sepharose & ETAAS & $\begin{array}{c}0.010 \mu \mathrm{g} / \mathrm{L} \mathrm{Cr}(\mathrm{III}) \\
\text { and } \\
0.020 \mu \mathrm{g} / \mathrm{L} \mathrm{Cr}(\mathrm{VI})\end{array}$ & $\begin{array}{c}0.02-0.28 \mu \mathrm{g} / \mathrm{L} \\
\mathrm{Cr}(\mathrm{III}) \text { and } 0.035-0.4 \\
\mu \mathrm{g} / \mathrm{L} \mathrm{Cr}(\mathrm{VI})\end{array}$ & $\begin{array}{c}4.7 \% \operatorname{Cr}(\mathrm{III}) \\
\text { and } 4.5 \% \\
\mathrm{Cr}(\mathrm{VI})\end{array}$ & $\begin{array}{c}\text { Environmental waters, } \\
\text { NIST } 1640 \text { and CRM } \\
320\end{array}$ & 42 \\
\hline
\end{tabular}

\section{Radionuclides}

\begin{tabular}{|c|c|c|c|c|c|c|c|c|}
\hline $\begin{array}{c}{ }^{90} \mathrm{Sr}_{,}^{241} \mathrm{Am} \text {, and } \\
{ }^{99} \mathrm{Tc}\end{array}$ & SI & $\begin{array}{c}\text { Sr-resin, TRU-resin, } \\
\text { TEVA resin (Eichrom } \\
\text { industries) }\end{array}$ & Liquid scintillation & NR & NR & $3 \%{ }^{90} \mathrm{Sr}$ & Nuclear waste & 40 \\
\hline
\end{tabular}

\section{Bioanalytical applications}

\begin{tabular}{|c|c|c|c|c|c|c|c|c|}
\hline $\begin{array}{l}\text { Biotin, DNA, } \\
\text { rabbit IgG }\end{array}$ & SI & $\begin{array}{l}\text { Lumavidin-coated } \\
\text { beads, peptide nucleic } \\
\text { acid-modified beads, } \\
\text { Protein A-coated } \\
\text { beads }\end{array}$ & $\begin{array}{l}\text { Flow cytometer } \\
\text { fluorometry }\end{array}$ & NR & $\begin{array}{l}\text { 1-100 } \mu \mathrm{g} / \mathrm{L} \text { (biotin) and } \\
\mathrm{g} / \mathrm{L} \text { level for DNA and } \\
\text { IgG }\end{array}$ & $<25 \%$ & $\begin{array}{c}\text { Binding assays/ } \\
\text { sandwich } \\
\text { immunoassays/ } \\
\text { multiplexed analysis }\end{array}$ & 12 \\
\hline IgG & SI-LOV & $\begin{array}{c}\text { Sepharose with } \\
\text { immobilized protein } \\
\text { G }\end{array}$ & Spectrophotometry & $\begin{array}{c}5 \mathrm{mg} / \mathrm{L} \text { (AC) and } \\
50 \mathrm{mg} / \mathrm{L} \text { (BIS) }\end{array}$ & $\begin{array}{c}0.100-1.00 \mathrm{~g} / \mathrm{L}(\mathrm{AC}) \\
\text { and } \\
0.100-0.400 \mathrm{~g} / \mathrm{L} \text { (BIS) }\end{array}$ & NR & $\begin{array}{l}\text { Human IgG, rabbit IgG, } \\
\text { horse IgG }\end{array}$ & 15 \\
\hline Mouse IgG & SI & $\begin{array}{l}\text { Magnetic beads with } \\
\text { immobilized } \\
\text { polyclonal sheep anti } \\
\text { mouse IgG }\end{array}$ & Fluorometry & $155 \mu \mathrm{g} / \mathrm{L}$ & $1-10 \mathrm{mg} / \mathrm{L}$ & $2.1 \%$ & $\begin{array}{l}\text { Competitive binding } \\
\text { assays of IgG }\end{array}$ & 21 \\
\hline Vitellogenin & SI & $\begin{array}{l}\text { Magnetic beads with } \\
\text { immobilized anti- } \\
\text { vitellogenin antibody }\end{array}$ & CL & $2 \mu \mathrm{g} / \mathrm{L}$ & $2-100 \mu \mathrm{g} / \mathrm{L}$ & NR & Standard solutions & 22 \\
\hline $\begin{array}{l}\text { Goat, anti-mouse } \\
\text { IgG }\end{array}$ & SI-LOV & $\begin{array}{l}\text { Protein G-coated } \\
\text { Sepharose 4B and } \\
\text { Protein A-coated } \\
\text { Sepharose 4B } \\
\end{array}$ & Spectrophotometry & $470 \mathrm{ng}$ & $0-0.4 \mathrm{~g} / \mathrm{L}$ & NR & $\begin{array}{c}\text { Interaction of antibodies } \\
\text { with protein A and } \\
\text { protein G via label } \\
\text { dilution } \\
\end{array}$ & 24 \\
\hline $\begin{array}{c}\text { GAD } 65 \\
\text { autoantibody }\end{array}$ & SI-LOV & $\begin{array}{l}\text { Streptavidin-coated } \\
\text { Sepharose 4B }\end{array}$ & Spectrophotometry & $20 \mu \mathrm{g} / \mathrm{L}$ & $100-400 \mu \mathrm{g} / \mathrm{L}$ & $<5 \%$ & Human serum/ELISA & 25 \\
\hline
\end{tabular}




\begin{tabular}{|c|c|c|c|c|c|c|c|c|}
\hline (type I diabetis) & & & & & & & & \\
\hline $\mathrm{H}_{2} \mathrm{O}_{2}$ & SI-LOV & $\begin{array}{c}\text { Live cells on } \\
\text { Cytodex-2 beads }\end{array}$ & Voltammetry & $9 \mu \mathrm{M}$ & $10-1000 \mu \mathrm{M}$ & NR & $\begin{array}{c}\text { Degradation rate of } \\
\mathrm{H}_{2} \mathrm{O}_{2} \text { by wild-type cells } \\
\text { or catalase- } \\
\text { overexpressing mouse } \\
\text { embryonic fibroblasts }\end{array}$ & 26 \\
\hline $\mathrm{pH}$ & SI-LOV & $\begin{array}{l}\text { Sephadex G-50 with } \\
\text { impregnated pH } \\
\text { indicator/ Cytopore } \\
\text { with immobilized live } \\
\text { cells }\end{array}$ & Spectrophotometry & NR & $7.2-7.4$ & $<8.38 \%$ & $\begin{array}{c}\text { Investigation of } \\
\text { extracellular } \\
\text { acidification rates of the } \\
\text { mouse hepatocyte cell } \\
\text { line TABX2S }\end{array}$ & 27 \\
\hline $\begin{array}{c}\text { Albumin, } \\
\text { ovalbumin, } \\
\text { lysozyme, human } \\
\text { IgG, ribonuclease } \\
\text { A and } \\
\text { cytochrome C }\end{array}$ & SI-LOV & $\begin{array}{c}\text { Aminolink agarose } \\
\text { beads }\end{array}$ & Spectrophotometry & NR & g/L level & NR & $\begin{array}{c}\text { Examination and } \\
\text { optimization of protein } \\
\text { immobilization protocols }\end{array}$ & 31 \\
\hline $\begin{array}{c}\text { Biotin-containing } \\
\text { conjugates and } \\
\beta \text {-galactosidase }\end{array}$ & SI-LOV & $\begin{array}{l}\text { Streptavidin-coated } \\
\text { agarose beads }\end{array}$ & $\begin{array}{l}\text { UV/Vis and } \\
\text { ESI-MS }\end{array}$ & NR & mg/L level & NR & $\begin{array}{c}\text { Determination of } \beta \text { - } \\
\text { galactosidase activity in } \\
\text { human cell } \\
\text { homogenates/ Kinetic } \\
\text { measurements of } \\
\text { dissociation rates of } \\
\text { model biotin-containing } \\
\text { conjugates }\end{array}$ & 39 \\
\hline $\begin{array}{l}\text { Lactate and } \\
\text { glucose }\end{array}$ & SI-LOV & $\begin{array}{c}\text { Cytopore with } \\
\text { immobilized live cells }\end{array}$ & Spectrophotometry & NR & $\begin{array}{c}0.05-1.00 \mathrm{mM} \text { (lactate) } \\
\text { and 0.1-5.6 mM } \\
\text { (glucose) }\end{array}$ & $\begin{array}{c}<7.3 \% \\
\text { (lactate) and } \\
7.1 \% \\
\text { (glucose) }\end{array}$ & $\begin{array}{l}\text { Lactate extrusion and } \\
\text { glucose consumption by } \\
\text { mouse hepatocyte cell } \\
\text { line TABX2S and } \\
\text { TABX1A }\end{array}$ & 47 \\
\hline DNA purification & SI-LOV & Silica beads & Fluorometry & NR & mg/L level & $3.8 \%$ & Human whole blood & 48 \\
\hline DNA & SI-LOV & $\begin{array}{l}\text { Streptavidin-coated } \\
\text { Sepharose 4B }\end{array}$ & Fluorometry & $1 \mathrm{pmol}$ & $\begin{array}{l}\text { 1-1000 pmol synthetic } \\
\text { DNA sequence }\end{array}$ & $<9.9 \%$ & Surrogate organism & 49 \\
\hline DNA & SI-LOV & $\begin{array}{l}\text { Streptavidin-coated } \\
\text { Sepharose 4B }\end{array}$ & Fluorometry & $111 \mathrm{pg}$ & $0-993 \mu \mathrm{g} / \mathrm{L}$ & NR & $\begin{array}{l}\text { Standards of biotinylated } \\
\text { single stranded DNA }\end{array}$ & 50 \\
\hline $\begin{array}{c}\text { Bone Alkaline } \\
\text { phosphatase }\end{array}$ & FI & $\begin{array}{c}\text { Wheat germ lectin } \\
\text { coated beads }\end{array}$ & Spectrophotometry & $10 \mathrm{U} / \mathrm{L}$ & $10-1000 \mathrm{U} / \mathrm{L}$ & $6 \%$ & Human serum & 51 \\
\hline
\end{tabular}




\begin{tabular}{|c|c|c|c|c|c|c|c|c|}
\hline \multicolumn{9}{|c|}{ Organic pollutants and drugs } \\
\hline $\begin{array}{l}\text { Promethazine } \\
\text { and } \\
\text { trifluoperazine }\end{array}$ & FI & $\begin{array}{c}\text { Sephadex QAEA-25 } \\
\text { (anion exchange) }\end{array}$ & Spectrophotometry & $\begin{array}{c}0.09 \mathrm{mg} / \mathrm{L} \\
\text { (promethazine) } \\
\text { and } 0.14 \mathrm{mg} / \mathrm{L} \\
\text { (trifluoperazine) }\end{array}$ & $\begin{array}{c}0.5-8 \mathrm{mg} / \mathrm{L} \\
\text { (promethazine) and } \\
0.5-10 \mathrm{mg} / \mathrm{L} \\
\text { (trifluoperazine) }\end{array}$ & $<2 \%$ & $\begin{array}{c}\text { Commercial } \\
\text { pharmaceutical } \\
\text { preparations }\end{array}$ & 18 \\
\hline $\begin{array}{c}\text { Alkylphenol } \\
\text { polyethoxylates }\end{array}$ & SI & $\begin{array}{l}\text { Magnetic beads with } \\
\text { immobilized anti- } \\
\text { alkylphenol } \\
\text { polyethoxylates } \\
\end{array}$ & $\overline{C L}$ & $10 \mu \mathrm{g} / \mathrm{L}$ & $1-1000 \mu \mathrm{g} / \mathrm{L}$ & $3 \%$ & River water & 23 \\
\hline $\begin{array}{c}\text { Ketoprofen, } \\
\text { naproxen, } \\
\text { bezafibrate, } \\
\text { diclofenac, } \\
\text { ibuprofen (NSAID) }\end{array}$ & $\begin{array}{l}\text { SI- } \\
\text { LOV- } \\
\text { MSFI }\end{array}$ & $\begin{array}{l}\text { poly-DVB-co-N- } \\
\text { vinylpyrrolidone }\end{array}$ & HPLC-UV & $0.4-40 \mu \mathrm{g} / \mathrm{L}$ & $0.02-0.67 \mu \mathrm{g} / \mathrm{L}$ & $<11 \%$ & $\begin{array}{l}\text { Urban wastewater, urine } \\
\text { and surface water }\end{array}$ & 44 \\
\hline $\begin{array}{c}\text { Muscarinic } \\
\text { receptor agonists } \\
\text { (carbachol, } \\
\text { acethylcholine } \\
\text { and pilocarpine) }\end{array}$ & FI & $\begin{array}{c}\text { Cytodex-2, } \\
\text { CultiSpher, Biosilon } \\
\text { and Cytodex-3 with } \\
\text { immobilized Chinese } \\
\text { hamster ovary cells }\end{array}$ & Fluorometry & $1 \mu \mathrm{M} \mathrm{Ca}$ & NR & NR & $\begin{array}{l}\text { Evaluation of drug } \\
\text { candidates }\end{array}$ & 46 \\
\hline
\end{tabular}

Acronyms: FI: Flow Injection, SI: Sequential Injection, LOV: Lab-on-Valve, MSFI: Multi-syringe flow injection, ETAAS: Electrothermal atomic absorption spectrometry, CL: Chemiluminescence, ESI-MS: Electrospray-mass spectrometry, HG-AFS: Hydride generation-atomic fluorescence spectrometry, $\mathrm{C}_{18}$-PS/DVB: poly(styrene-divinylbenzene) copolymer alkylated with octadecyl groups, PTFE: Polytetrafluoroethylene, ARS: Alzarin Red S, PAN: 1-(2-pyridylazo)-2-naphthol, DPC: 1,5-diphenylcarbazide, AC: Affinity chromatography, BIS: Bead-Injection spectroscopy, CL: Chemiluminescence, ELISA: Enzyme-linked immunosorbent assays, NSAID: non-steroidal anti-inflammatory drugs, NR: No reported 